\title{
11
}

\section{Country and Kin Calling? Keith Hancock, the National Dictionary Collaboration, and the Promotion of Life Writing in Australia ${ }^{1}$}

\author{
Melanie Nolan
}

\section{Australian historians and ego-histoire}

In his international comparison of history, historians and autobiography in 2005, Jeremy D. Popkin concluded that Australian historians were early to, and enthusiastic about, the ego-histoire movement or the 'setting down [of] one's own story'. Australians anticipated Pierre Nora's collection of essays, Essais d'ego-histoire, which was published in $1987 .{ }^{2}$ They had already founded 'a series of autobiographical lectures in 1984', which resulted in a number of publications, and Australian historians' memoirs thereafter appeared at a rate of more than one a year. ${ }^{3}$ When he considered Australian

\footnotetext{
1 I thank Ann Curthoys and the editors for their comments on an earlier draft.

2 Pierre Nora ed., Essais d'ego-histoire (Paris: Gallimard, 1987), 7.

3 Jeremy D. Popkin, History, Historians, \& Autobiography (Chicago/London: University of Chicago Press, 2005), 74. In 'Ego-histoire Down Under: Australian Historian-Autobiographers', Australian Historical Studies, 38:129 (2007), 110, doi.org/10.1080/10314610708601234, Popkin dates the Australian memoir bulge from 1982 when collective projects including 'a volume of professional women's narratives, The Half-Open Door, which appeared in 1982, and the four volumes of essays starting with the Victorian History Institute's 1984 forum in which R.M. Crawford, Manning Clark and Geoffrey Blainey participated'. Patricia Grimshaw and Lynne Strahan, eds, The Half-Open Door: Sixteen Australian Women Look at Professional Life and Achievement (Sydney: Hale \& Iremonger, 1982);
} 
historians' memoirs more specifically in 2007, Popkin argued that '[o]n a proportional basis, more historians from Australia than from any other country' have written ego-histoire: he had identified 'more than three dozen different' Australian historians who had written her or his memoirs compared to just 200 United States historians' published memoirs. ${ }^{4}$ Popkin also argued that contemporary Australian historians' memoirs helped to establish 'a tradition of first-person writing, a relatively recent development in their own culture' and that they had greater impact in Australia than groups of other historians elsewhere in other countries. Works by both male and female authors such as Keith Hancock, Kathleen Fitzpatrick, Bernard Smith, Jill Ker Conway, Manning Clark, Ann Moyal and Inga Clendinnen constituted a distinctive strain of historical life writing generally and had become major contributions to the national literature. ${ }^{5}$ This creative nonfiction won major mainstream literary prizes, not simply specialist history ones. Australian historians' life writing had a greater impact within society than French or US contemporaries had in theirs, according to Popkin, because of the literary quality of the work and the 'high degree of authorial self-consciousness' in the context of a relatively new sense of Australian cultural identity.

This work has been methodologically important to the profession, too, in two ways. First, historians' personal lives and experience challenged received versions of the national past. Popkin argued:

Australian historians have used their personal stories to dramatise the issue of Australia's relationship to Britain and Europe, its ability to define a distinctive national personality, the role of gender in that definition and how Australia might come to terms with its troubled relationship to its Aboriginal population. ${ }^{6}$

R.M. Crawford, Manning Clark and Geoffrey Blainey, Making History (Melbourne: McPhee Gribble/ Penguin, 1985); Bain Attwood, ed., Boundaries of the Past (Melbourne: History Institute, 1990); Bain Attwood and Joy Damousi, eds, Feminist Histories (Melbourne: History Institute, 1991); Bain Attwood, ed., Labour Histories (Melbourne: Monash University Printing Services, 1994).

4 Popkin, 'Ego-histoire Down Under', 110, 119.

5 W.K. Hancock, Country and Calling (London: Faber \& Faber, 1954); Hancock, Professing History (Sydney: Sydney University Press, 1976); Kathleen Fitzpatrick, Solid Bluestone Foundations: Memories of an Australian Girlhood (Ringwood: Penguin, 1983); Jill Ker Conway, The Road from Coorain (New York: Knopf, 1989); Manning Clark, The Puzzles of Childhood (Ringwood: Viking, 1989); Clark, The Quest for Grace (Ringwood: Viking, 1990); Bernard Smith, The Boy Adeodatus: The Portrait of a Lucky Young Bastard (Melbourne: Oxford University Press, 1990); Ann Moyal, Breakfast with Beaverbrook: Memoirs of an Independent Woman (Sydney: Hale \& Iremonger, 1995); Inga Clendinnen, Tiger's Eye: A Memoir (Melbourne: Text Publishing, 2000). For instance, Smith's Adeodatus won both the Victorian Premier's Literary Award and the National Book Council Prize.

6 Popkin, 'Ego-histoire Down Under', 123. 
Indeed, Indigenous Australian historians' autobiographies, including those of Gordon Briscoe and of the contributors to the recent collection, Ngapartji Ngapartji, discussed how these scholars' life histories have impacted on their research on Indigenous Australians and their more general perspectives, just as occurred for women historians earlier. ${ }^{7}$ Their experience led them to question the national Australian narratives. Second, autobiographical works also helped to break down the wall or methodological divide between history and autobiography, which had been premised on the view that memoirs were private, subjective and 'beyond the reach of historical investigation' while history was researchbased and in accordance with the documentary record. ${ }^{8}$ Many others have questioned what is sometimes described as the 'illusion of objectivity', but ego-histoire confronted this issue directly in terms of source material. ${ }^{10}$ Not only did many memoirists resort to documentary evidence but historians, as well as biographers, used subjective material. As Popkin argued, biographies of historians and their own ego-histoire were important factors in the wider reconciliation between history and autobiography. ${ }^{11}$

Popkin singled out the trailblazing importance for Australian historians of W.K. (Keith) Hancock's reflections: his 1954 volume of memoirs, Country and Calling, and his 1976 extended autobiographical essay, Professing History. ${ }^{12}$ Historians regard Hancock as Australiass greatest historian because he displayed an impressive range, quality and volume of work. He also held an impressive range, quality and number of political involvements, appointments and honours. ${ }^{13}$ Hancock's biographer, Jim Davidson, notes that 'Hancock's once immense reputation is now hard for Australians to

7 Gordon Briscoe, Racial Folly: A Twentieth Century Aboriginal Family (Canberra: ANU E Press and Aboriginal History, 2010); Vanessa Castejon, Anna Cole, Oliver Haag and Karen Hughes, eds, Ngapartji Ngapartji: In Turn, in Turn: Ego-histoire, Europe and Indigenous Australia (Canberra: ANU Press, 2014).

8 Popkin, History, Historians, \& Autobiography, 17, 90.

9 Peter Novick, That Noble Dream: The 'Objectivity Question' and the American Historical Profession (Cambridge: Cambridge University Press, 1988), doi.org/10.1017/CBO9780511816345.

10 Luisa Passerini and Alexander Geppert, 'Historians in Flux: The Concept, Task, and Challenge of Ego-histoire', Historein: A Review of the Past and Other Stories, special issue, European Ego-histoires: Historiography and the Self, 1970-2000, 3 (2001), 7-18.

11 Popkin, History, Historians, \& Autobiography, 12.

12 Hancock, Country and Calling; Hancock, Professing History; Popkin 'Ego-histoire Down Under', 109. See also Jaume Aurell, Theoretical Perspectives on Historians' Autobiographies: From Documentation to Intervention (New York/London: Routledge, 2015), 485 - together with G.V. Portus's autobiography, Happy Highways (Melbourne: Melbourne University Press, 1953); and David McCooey, Artful Histories: Modern Australian Autobiography (Cambridge: Cambridge University Press, 1996), doi.org/10.1017/ CBO9781139084956.

13 D.A. Low, ed., Keith Hancock: The legacy of an Historian (Melbourne: Melbourne University Press, 2001). 
grasp: most of it was earned outside Australia, and the Commonwealth context which gave it coherence has virtually collapsed'. ${ }^{14}$ Stuart Macintyre famously suggested in 2010 that if there were a Nobel Prize for History, Hancock would surely have won it'. ${ }^{15}$ Hancock (1898-1988) attained a First in History at Melbourne University (BA Hons, 1920), and was a temporary lecturer at the University of Western Australia before taking up a Rhodes Scholarship to Balliol College, Oxford (BA, 1923; MA, 1930). He secured a prize fellowship at All Souls (1923) and the next year, at the age of 26, he became a 'boy professor' of history at Adelaide University (1924-34). $\mathrm{He}$ then held chairs successively at Birmingham (1934-44), Oxford (1944-49), Institute of Commonwealth Studies London (1949-56) and The Australian National University (ANU) (1957-65). He became an ANU Visiting Fellow and founding director of the Australian Academy of the Humanities in 1969 in his 'retirement'. Hancock wrote more than 20 books: most importantly, Australia (1930), Survey of British Commonwealth Affairs (1937-42), British War Economy (with Margaret Gowing, 1949), Smuts: The Sanguine Years, 1870-1919, vol. 1 (1962), Smuts: The Fields of Force, 1919-50, vol. 2 (1968), and Discovering Monaro (1972), as well as his two works of professional memoir and reflection. His British knighthood in 1953 stemmed from his most famous service in managing and editing the 28 volumes of the British Civil Histories of War. Hancock was involved in a mission to Uganda on behalf of the British government in 1954. The Italian government appointed him to the Order of Merit of the Republic of Italy in 1961, on the strength of his first, and least known, work on Ricasoli and the Risorgimento in Tuscany in 1926, which Mussolini's ascendancy had rendered relevant. The Australian government instigated his Knight Commander of the Order of the British Empire award in 1965 primarily for his role at ANU, with which he had been associated from its foundation in 1946 when he was one of the inaugural four 'academic advisors'. ${ }^{16}$

Australian historians' struggle with the challenge of writing 'their own history' was played out poignantly in Hancock's own biographical practices, negotiating the conflicts of a historian writing his own history

14 Jim Davidson, A Three-Cornered Life: The Historian W. K. Hancock (Sydney: University of New South Wales Press, 2009), 510.

15 Tom Griffiths, The Art of Time Travel: Historians and their Craft (Carlton, Vic.: Black Inc., 2016), $42-60$

16 See, for instance, Robin Gollan, 'Sir (William) Keith Hancock 1898-1988', Proceedings of the Australian Academy of Humanities, vol. 14 (Canberra: Australian Academy of the Humanities, 1990), 61-63; and Jim Davidson, 'Hancock, Sir William Keith (1898-1988)', Australian Dictionary of Biography, vol. 17 (Melbourne: Melbourne University Press, 2007). 
and the separate dilemma of what he called 'country and calling' during the twentieth century. First, Hancock's writings and life abound with tensions arising from his being both an insider and outsider: Davidson describes a three-cornered life in terms of country, while Sandra Holton argues that he never resolved the dilemmas of being an Antipodeanborn European. ${ }^{17}$ Second, Hancock's two volumes of memoirs epitomise the struggle he had in disentangling the personal and the professional. Reviewers noted that the 'best part' of his first memoir was his childhood reminiscences. ${ }^{18}$ While his first wife, Theaden Brocklebank, is deliberately excluded from discussion in the first volume, she does appear in the second volume. ${ }^{19} \mathrm{He}$ also 'draws a veil' over disagreements he had with other scholars at ANU, observing that 'those stories better not be told'. ${ }^{20}$ Hancock, as an Australian historian writing his memoirs, had a lot of work to do in defending his positions on the nation, as well as the extent to which he wrote about his professional and personal life. One aspect of Hancock's engagement with Australian life writing, which Popkin neglects, is Hancock's being the leading figure in the establishment of the Australian Dictionary of Biography $(A D B)$ at ANU in the late $1950 \mathrm{~s}^{21}{ }^{21}$ Three decades later, there were 306 biographies of historians in the $A D B$ for the period between 1788 and 1990; nearly 2.5 per cent of the $A D B$ 's 12,500 subjects who died before 1990 are fielded, or indexed, as 'historians'. ${ }^{22}$ In this way, Hancock was responsible for the writing of many Australian historians' lives as well as his own.

While Hancock struggled with being himself the subject of a biography, his ambivalence waned over time. ${ }^{23} \mathrm{He}$ had begun pondering his life in the light of R.G. Collingwood's autobiography. Hancock initially bridled at Davidson's suggestion of a biography on himself. He had after all

17 Sandra Stanley Holton, 'The Autobiographies: Country and Calling and Professing History' presented at a 'Sir Keith Hancock Symposium' held in The Australian National University in Canberra in 1998, for the centenary of Hancock's birth and 10 years after his death; and "'History is about Chaps”: Professional, National and Gender Identities in Hancock's Autobiographies', in Low, Keith Hancock, 271.

18 C.E. Carrington, review of Country and Calling by W.K. Hancock, International Affairs, 31:2 (1955), 210.

19 O'Brien, review of $A$ Three-Cornered Life; Holton, "'History is about Chaps", 271.

20 Moyal, Breakfast with Beaverbrook, 137-49, tells the stories, as does Davidson, A Three-Cornered Life, ch. 6.

21 Melanie Nolan and Christine Fernon, eds, The ADB's Story (Canberra: ANU E Press, 2013).

22 See $A D B$ website, adb.anu.edu.au/facets/?facet=occf, for a breakdown of the distribution among 13 categories: general (188), military (40), religious (15), economic (11), architecture (8), art (7), music (6), medical (5), labour (4), legal (4), political (3), social (3), and literary (2).

23 See Davidson, A Three-Cornered Life, 485, for a discussion of his change of mind on this issue. 
burned all his and his first wife Theaden's correspondence after her death, although he used extensive 'records I kept at that time of her state of health. ${ }^{24}$ As he warmed to the idea, Hancock teased Davidson by showing him personal diaries and personal papers that he was (literally) not allowed to touch. At the launch of Volume 10 of the $A D B$ in 1986, however, Hancock publicly praised Davidson's biography of Dame Nellie Melba as the 'best brief life of a prima donna that anyone has ever written or ever will write'. ${ }^{25}$ Melba's article was controversial for its explicit discussion of her facelift as the cause of her death from septicaemia. ${ }^{26}$ Hancock opined that $A D B$ articles were 'more scholarly' than the British Dictionary of National Biography $(D N B)$ articles because $A D B$ authors had 'delved deep into primary sources' and wrote on a wide variety of subjects. That evening, Davidson said that privately Hancock gave him an 'encoded message of approval' to be his biographer. ${ }^{27}$

In various ways, Hancock was not only central to overcoming a general reluctance towards all forms of life writing in Australia, and by and for historians in particular, but also to influencing the kind of biography written. In leading the way, he was not only party to, but also a subject of, the transition. As Macintyre noted in the 1998 Companion to Australian History ' $[\mathrm{h}]$ istorians have largely dropped their suspicion of the genre of biography'; now, ' $[\mathrm{t}]$ hose who regard biography as a mere ancillary of their discipline underestimate it'. ${ }^{28}$ Popkin, of course, did not consider biographies of historians in his analysis. Indeed, many commentators continue to distinguish between history and biography, and by kinds of life writing, too. While they include autobiographies, they draw the line at memoirs, believing autobiographies to be fuller and documented, while memoirs are mere perspectives based on memory. ${ }^{29}$ However, I would argue that this refined distinction is still fraught; at the very least there is a continuum. Jaume Aurell has noted that some historians 'design their autobiographies in the same way as they articulate their historical texts'.

24 Hancock, Professing History, 24.

25 W.K. Hancock, speech notes, launch of vol. 10, ADB, Box 116, Q31, ADB Archives (ADBA), Australian National University Archives (ANUA).

26 Jim Davidson, 'Melba, Dame Nellie (1861-1931)', Australian Dictionary of Biography, National Centre of Biography, The Australian National University, adb.anu.edu.au/biography/melba-damenellie-7551/text13175, published first in hardcopy 1986 (accessed 6 October 2016).

27 Davidson, $A$ Three-Cornered Life, x.

28 Graeme Davison, John Hirst and Stuart Macintyre, eds, The Oxford Companion to Australian History (Melbourne: Oxford University Press, 1998), 72.

29 Robert Drewe, Seymour Biography Lecture, 17 September 2015, National Library of Australia (NLA), www.nla.gov.au/audio/robert-drewe; McCooey, Artful Histories, 5, also distinguishes between history and autobiography. 
We can consider some autobiographies as a valid form of history, and one might include some memoirs too. ${ }^{30}$ For instance, biographies have increasingly been based, in turn, on rich 'first-person' archival material, diaries and correspondence. Some memoirs are increasingly researched and are referenced. If autobiographies break down the methodological divide between history writing and subjective sources, so too can biographies.

In the face of debates about the differences between primary and secondary life writing, and amidst a current multitude of memoirs by, and biographies about, Australian historians, in this essay I consider the history of biographical practices among those in the Australian academy from the vantage point of Hancock's experience. I chart the history of Australian historians' memoirs and biographies and their changing natures, considering especially the recent emergence of historians' family memoirs. This analysis complements assessments, such as Popkin's, which concentrate on national identity; it seeks to broaden the changes in quantity and kind of life writing over time that we should consider.

\section{Kick-starting Australian biography writing}

Hancock and the $A D B$ were central to the evolution of Australian biography from the foundation of ANU. When planning for ANU began in earnest at the end of the Second World War, H.C. Coombs was charged with consulting expatriates, such as Hancock, on the shape of the new research university. Hancock, together with medical scientist Sir Howard Florey, physicist Mark Oliphant and anthropologist Raymond Firth made up the Academic Advisory Committee, which met the Interim Council in Canberra over Easter 1948 to discuss the university. The committee invited Hancock to advise it on the proposed school of social sciences. In turn, in preparation, Hancock invited a number of Australian social scientists to report on recent developments in their fields, their opinion on the main directions for future research, and 'the facilities which are necessary for the encouragement of research'. Professor R.M. (Max) Crawford at the University of Melbourne wrote the survey on the discipline of history. He argued generally that social scientists needed to be 'brought together' in Canberra. In terms of history, there were seven great needs: the collection, preservation and cataloguing of documents;

30 Jaume Aurell, 'Autobiography as Unconventional History: Constructing the Author', Rethinking History, 10:3 (2006), 433-49, doi.org/10.1080/13642520600816213. 
public policy history; interpretative histories of Australia (Melbourne was planning a five-volume history of Australia); regional history; histories of private institutions; Pacific history; and biography.

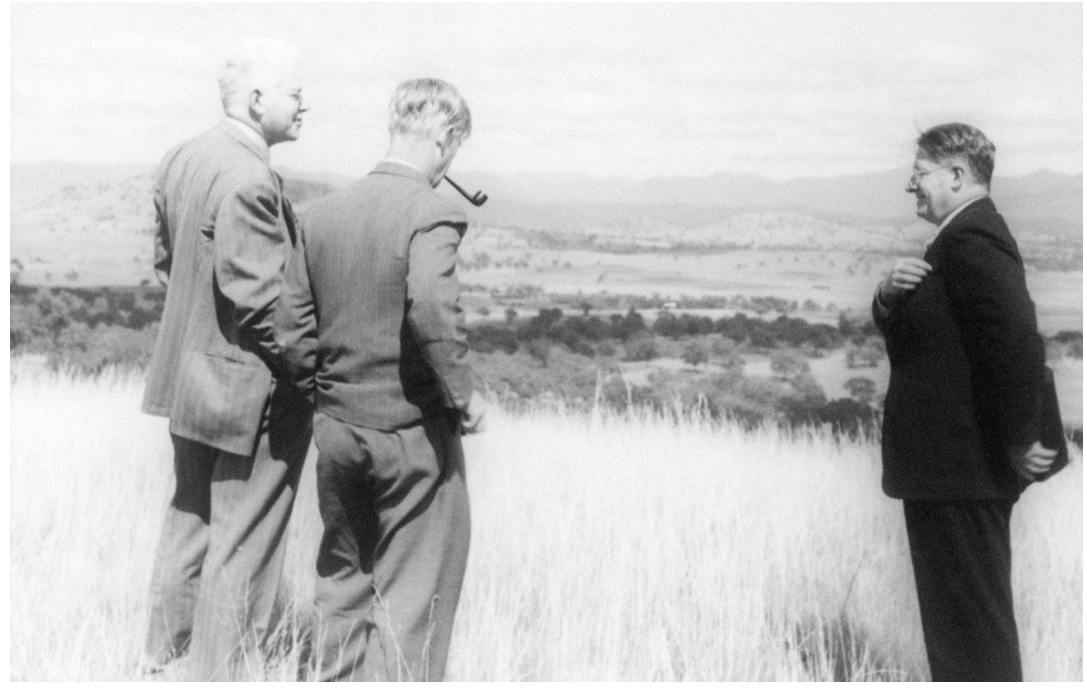

Three of the academic advisors, Mark Oliphant, Keith Hancock and Howard Florey, reviewing proposed sites for ANU, Canberra, Easter 1948

Source: Oliphant Papers, Barr Smith Library, University of Adelaide. Reproduced in Stephen Foster and Margaret Varghese, The Making of the Australian National University 1946-1996 (St Leonards, NSW: Allen \& Unwin, 1996), p. 44. openresearch-repository.anu. edu.au/handle/1885/11333.

Above all, Crawford saw a special role for the ANU historians in a dictionary project: ' $[t]$ here is, I believe, more work being done now in Australia biography, a field in which we have in the past done relatively little'. Crawford provided a list of just three dozen biographies of published between 1933 and 1947. ${ }^{31}$ Similarly, H.M. Green's survey of biography as part of a more general survey of Australian literature in 1951 argued that the first Australian biographies were akin to 'extended, more considered, and permanent version of the obituary'. Green pointed to just three 'outstanding' Australian biographies before the 1950s: Nettie Palmer's biography of her uncle and High Court Judge, Henry Bournes

31 Raymond Maxwell Crawford, 'Present state of historical research in Australia, and comments on main directions which research may take', Research in the Social Sciences in Australia, Reports Prepared at the Request of Professor Keith Hancock, January 1948, tabled in the Minutes, 10 October 1947, p. 3, ANU Council, box 26, series 19, ANUA. This study was subsequently published as Research in the Social Sciences in Australia: Reports Prepared at the Request of Professor W.K. Hancock (Canberra: The Australian National University, 1948). 
Higgins; M. Barnard Eldershaw's Phillip of Australia ('the' author was, in reality, a professional collaboration between Marjorie Barnard and Flora Eldershaw, the subject being Arthur Phillip, the first governor of New South Wales (NSW), 1788-92); and H.V. Evatt's Australian Labour Leader, a memoir of William Holman, NSW Premier 1913-20. ${ }^{32}$ Crawford distinguished between the historian's and ANU's roles:

I do not need to labour the point that biographical studies will teach us about much more than the persons studied. This is work for individual scholars. The role of the National University might be the eventual production of an Australian Dictionary of National Biography. ${ }^{33}$

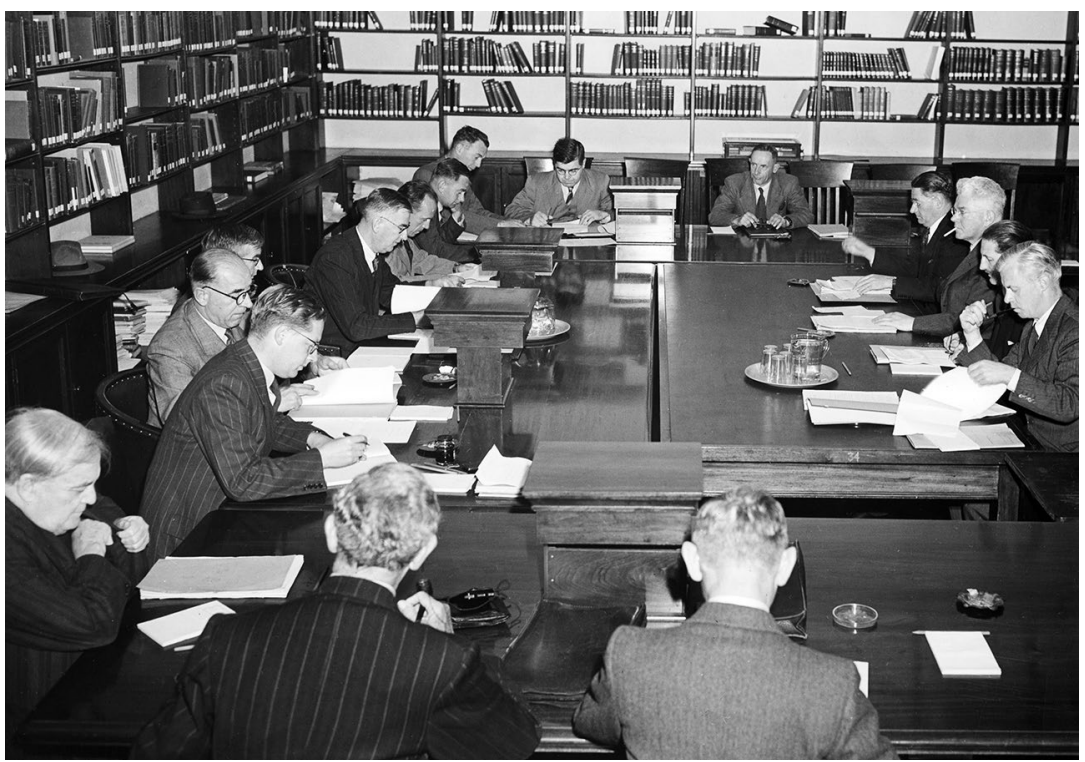

Interim Council meeting with academic advisors, April 1948

Pictured from left, moving clockwise around table (according to writing on back of photograph): Sir Frederic Eggleston, Ernest Clark, Professor D. Copland, R.G. Osborne, Professor R.C. Mills, Dr H.C. Coombs, A.S. Brown, Mr Goodes, Professor R.D. Wright, Mr McDonald, Lord Florey, Professor M. Oliphant, Professor R. Firth, Professor K. Hancock, C.S. Daley and Sir Robert Garran.

Source: Australian official photograph, Department of Information (photographer unknown).

32 H.M. Green, A History of Australian Literature, Pure and Applied: A Critical Review of all Forms of Literature Produced in Australia from the First Books Published After the Arrival of the First Fleet until 1950 (Revised ed.; 2 vols.; Sydney: Angus \& Robertson, 1985), II, 1367-92; Nettie Palmer, Henry Bournes Higgins (London: Harrap, 1931); M. Barnard Eldershaw, Phillip of Australia (London: Harrap, 1938); H.V. Evatt, Australian Labour Leader: The Story of W.A. Holman and the Labour Movement (Sydney: Angus \& Robertson, 1942).

33 Crawford, 'Present state of historical research in Australia', 3. 
This proposal struck a chord with Hancock. The ANU charter was a nation-building one: to encourage, and provide facilities for, research and postgraduate study, both generally and in relation to subjects of national importance to Australia. ${ }^{34}$ The dictionary project could play a tangible role in promoting Australian history. Above all, no other Australian university was in a position to develop a dictionary project, and ANU could show intellectual leadership in this regard and develop a national collaboration around the project. Hancock had been slightly involved in the DNB in wartime Britain, serving on its national committee. In his biography, Davidson cites Hancock's role in the $D N B$, as do others, observing that he 'rarely thought it worth mentioning'. ${ }^{35}$ Perhaps he did not mention it because the $D N B$ was not an elaborate organisation at this time: Hancock is thanked in a list of 86 others in the supplementary volume on Britons who died between 1941 and 1950, and is thanked along with 43 others for 'their advice' in the decadal successor of those who died between 1951 and $1960 .{ }^{36}$ The project was an 'Oxford project' and Hancock was friends with both editors, L.G. Wickham Legg and Bill Williams; the latter was a co-fellow of Balliol and a Warden of Rhodes House, itself a centre for Commonwealth Studies, Hancock's specialty. The editors did not have a national collaborative network; they were merely adding supplements to Leslie Stephen and Sidney Lee's initial project. Hancock's honing of skills in a large collaborative historical project in Britain arose not from the $D N B$ but primarily from the series of histories about the nation at war that he designed and managed for the War Histories Branch, attached to the Cabinet Office. His plan for this undertaking was approved and he appointed 10 historians. He thus became general editor for the next dozen years on the 28 volumes that comprised the Civil Histories of the History of the Second World War, his duties involving not only writing the first volume but also managing directly for five years about 40 historians and researchers. ${ }^{37}$

34 Hon. John Johnstone Dedman, MP, Minister for Post-War Reconstruction, 'Second Reading Speech - Australian National University Bill 1946', Hansard, 19 June 1946.

35 Davidson, A Three-Cornered Life, 393.

36 L.G. Wickham Legg and E.T. Williams, eds, The Dictionary of National Biography, 1941-1950 (Oxford: Oxford University Press, 1959), v.

37 The War Histories Branch of the Cabinet Office staff numbered 122 in 1949, of whom 20 were employed part time. The 28 historians and 48 researchers were divided about equally between military and civil histories of the war. See Jose Harris, 'Thucydides Amongst the Mandarins: Hancock and the World War II Civil Histories', in Low, Keith Hancock, 122-48. 
Others have narrated the difficulty ANU experienced in appointing Hancock the inaugural director of the Research School of Social Sciences. ${ }^{38}$ He did not take up that position up until 1957. Meanwhile, Laurie Fitzhardinge was drumming up support for a dictionary of Australian biography. Fitzhardinge taught classics at the University of Sydney from 1946 to 1950 . He was charged with setting up a Sydney University press, which involved his travelling, with his family, to Britain for a year in 1947 to 1948 to visit university printing presses. He was based at the Clarendon Press at Oxford University. He spent a brief afternoon at the Dictionary of National Biography with the editor of the supplement, Hancock's friend Wickham Legg, who had been Fitzhardinge's moral tutor in New College, Oxford, from 1931 to 1933 . Fitzhardinge thought that a dictionary of biography should be a flagship project for a nascent university press. ${ }^{39}$ He loved dictionaries himself; wet Sunday afternoons of his childhood spent reading his way through the Dictionary of National Biography in his school library had been 'an endless source of enjoyment ... I devised games, dodging about in it, opening a volume at random and then following all the cross references and following up the cross references to that, and so on'. ${ }^{40}$ His experience of working at the National Library from 1934 to 1944 and writing Australian biography taught him how 'very difficult' it was 'to get even the most elementary background information about the people, the cast'. Finally, the publication of Percival Serle's two-volume Dictionary of Australian Biography in 1949 convinced Fitzhardinge that writing biographical dictionaries was 'no longer a one-man job. It's got to be a team job on the model of the DNB'. ${ }^{41}$

At Oxford, on the advice of R.C. Mills, the chair of the interim council at ANU, Fitzhardinge gave Hancock his report on the resources of the National Library. Hancock was impressed with Fitzhardinge and wanted to employ him as a bibliographical consultant on local materials for the various high-powered heads of schools that he was proposing to bring out to ANU. The Sydney University press project was aborted in 1948. When he was appointed Reader in the Sources of Australian History at ANU

38 Davidson, A Three-Cornered Life; Gerald Walsh, 'Recording "the Australian Experience": Hancock and the Australian Dictionary of Biography', in Low, Keith Hancock, 249-68. See also Nolan and Fernon, The ADB's Story, 5-9.

39 Keith Hancock, 'Formation of the Australian Dictionary of Biography', Box 69, Q31, ADBA, ANUA.

40 Laurie Fitzhardinge, Interview by Barbara Ross, 4-26 March 1987, TRC 2159, transcript, NLA, p. 2.

41 Fitzhardinge, interview by Ross, 1987. 
on Hancock's recommendation in 1951, Fitzhardinge proposed that the ANU press project produce a dictionary of biography as its flagship. Again he was unsuccessful. He suggested the dictionary idea more widely at the 1951 Australian and New Zealand Association for the Advancement of Science (ANZAAS) Conference, and started a Biographical Register in the history department at ANU in $1954 .{ }^{42}$ As Head of History, Fitzhardinge employed Pat Tillyrand and others to work on the card index, 'building up material' for a dictionary. ${ }^{43}$ Later, Fitzhardinge described his efforts as 'a typically Fitzhardingian feeble and waffly attempt' to get the dictionary off the ground: 'I'd prepared a plan for the preparation, within our resources more or less, of a dictionary of biography - not to be written by the Department, to be an all-over effort, but not to be attempted all at once. ${ }^{44} \mathrm{He}$ envisaged the annual publication of articles contributed by Australian historians, which would build up, over the years, into a dictionary of concise articles organised alphabetically.

Fitzhardinge acknowledged that it was Hancock, however, finally arriving as inaugural professor of history and director of the Research School of Social Sciences (RSSS) in 1957, who seized upon the dictionary idea and 'turned imaginatively a set of cards into a great national achievement of historical scholarship..$^{45} \mathrm{He}$, Fitzhardinge admitted, 'could do things which I would never have been able to do in a month of Sundays'. Drawing on his experience of overseeing the Civil Histories, Hancock set about organising a national collaboration. He wrote to all the professors of history and economic history, and all specialists in Australian history, inviting them to a conference in August 1957, together with nonacademic historians (including journalist-historians Malcolm Ellis and Brian Fitzpatrick, Catholic archbishop and historian Dr Eris O'Brien and military historian Gavin Long), to discuss how to 'advance the study of Australian history'. ${ }^{46}$ Ellis was one of the few attending who had both written biography and reflected on Australian biographical practice. He had published biographies of pastoralist John Macarthur, Governor

42 W. K. H. [Hancock], 'The ADB' (12 April 1962), Box 69, Q31, ADBA, ANUA. 'Excerpt from Statement prepared by Professor Hancock. Formation of the Australian Dictionary of Biography', Box 69, Q31, ADBA, ANUA.

43 George Temperly, Obituary 'Patience (Pat) Australie Wardle nee Tillyard (20 June 1910-22 April 1992)', Canberra Historical Journal, no. 30 (September 1992), 5-7.

44 Fitzhardinge, interview by Ross, 1987.

45 'Notes and News, Arrival of Hancock in Canberra', Historical Studies, 7:28 (1957), 486-7.

46 Fred A. Alexander, Boyce Gibson, Margaret Gowing and Robin Gollan, 'Hancock: Some Reminiscences', Historical Studies, 13:51 (1968), 229-306, doi.org/10.1080/10314616808595379. 
Lachlan Macquarie and architect Francis Greenway. He was on record in 1955 as describing most Australian biographies as being like 'licking the cold outside of a champagne bottle on a thirsty day. ${ }^{47}$ Hancock, however, deftly steered the conversation of this first conference, by, and for, Australian historians, towards a dictionary project: by the end, they agreed that a 'Concise Dictionary of Australian Biography' was the single most important priority for stimulating the development of Australian history. ${ }^{48}$

As well as Hancock's first publication in 1926 on Ricasoli as dictator of Tuscany, he had lectured on Machiavelli's morality and expediency, and in the early 1950s he began to research General Jan Christiaan Smuts' biography. He was not hampered in his own biographical projects by lack of knowledge of milieu, but he was aware that some of his colleagues thought the problem of a lack of historiographical context was acting as a governor on the writing of Australian biography. As late as during the 1930s, academics such as Gerry Portus had maintained that 'Australian history was not deserving of being a university subject'. ${ }^{49}$ Ernest Scott introduced a course at Melbourne in the early 1930s; in 1946, Clark became the second historian to teach a full-length course in Australian history, and he was soon followed by others. ${ }^{50}$ Moreover, Fred Johns, whose 1906 Johns's Notable Australians was the precursor of Who's Who in Australia, had wanted to stimulate academic biography and bequeathed the sum of $£ 1,500$ to the University of Adelaide in 1932 for the purpose of founding 'the Fred Johns Scholarship for Biography' to encourage the writing of biographies on eminent Australians. ${ }^{51}$ The scholarly journal Historical Studies: Australia and New Zealand had been founded in 1940 and a body of scholarly articles on Australian history was being published. The journal's editor from 1940 to 1949, the historian Gwyn James, had

47 Malcolm Henry Ellis, 'The Writing of Australian Biographies', Historical Studies, Australia and New Zealand, 6:24 (1955), 432, doi.org/10.1080/10314615508595013.

48 Robin Gollan, 'Canberra History Conference', Historical Studies, Australia and New Zealand, 8:29 (1957), 81, doi.org/10.1080/10314615708595099; Ellis, 'The Writing of Australian Biographies', 432. W. K. H. [Hancock], 'The ADB' (12 April 1962), Box 69, Q31, ADBA, ANUA; 'Excerpt from Statement prepared by Professor Hancock. Formation of the Australian Dictionary of Biography', Box 69, Q31, ADBA, ANUA; Stuart Macintyre, 'Biography', in Davison et al., The Oxford Companion to Australian History, 72.

49 Mark McKenna, An Eye for Eternity: The Life of Manning Clark (Melbourne: Miegunyah Press, 2011), 250.

50 My thanks to Stuart Macintyre for drawing my attention to Scott's pioneering course at Melbourne, email, 9 July 2016.

51 Johns's Notable Australians became Who's Who in Australia, published in 1927-8, 1933-4, 1935, 1938, 1941, 1944, 1947, 1950 and 1955; and then triennially from 1959 to 1988. 
also been appointed director of Melbourne University Press (MUP) and, over the period of his tenure from 1943 to 1962, he began to welcome academic biography..$^{52}$ Academic historians began to publish biography, including Margaret Kiddle on Caroline Chishom with MUP in 1957 and others followed such as George Mackaness and Kathleen Fitzpatrick. Fitzhardinge himself seriously began his biography of W. Hughes in 1952 (although volume one did not appear until 1964 and volume two in 1979). ${ }^{53}$

So an Australian dictionary of biography project in the late 1950s was a timely proposal. There was a developing disciplinary infrastructure, as well as a broader historical consciousness. Indeed, writing in 1962, Green noted that Australian history 'stretches out behind its present like a long wake' and was being populated; the developing universities were providing 'biographers with opportunities' but, above all, a large element in Australia 'in the best sense' had become 'literate'. ${ }^{54}$ Australia had 6 universities and approximately 10,500 students before 1939; there were 10 universities with 53,000 students by 1960; there were 19 universities with 148,000 students by $1975 .{ }^{55}$ The number of historians grew in leaps and bounds.

There was also agreement among those who attended the 1957 conference that the growing sources in Australia would sustain good biography, taking account of human agency and consciousness. Australian historians' intellectual reference point was the English historical philosopher and idealist R.G. Collingwood, who emphasised not how a biographical subject might appear from an external perspective but rather how the person's thought processes could be assessed. Collingwood argued in The Idea of History that history consisted of 'recollection' of the 'thinking of historical personages. ${ }^{56}$ This required depth of evidence and the maturity to interpret it. It required biographical understanding, too. Similarly, Wilhelm Dilthey had written on how the past is based on personal memory and the importance of narrative to ideas of subjectivity. He held

52 Peter Ryan, Final Proof: Memoirs of a Publisher (Sydney: Quadrant Books, 2010).

53 Argus, 9 December 1952, 3. Stephen Foster interview of L.F. Fitzhardinge on 5 August 1992, ANU History Project, ANUA 44, Transcripts and tapes of oral history interviews, interview no. 26 by Stephen Foster, 5 August 1992, pp. 14-17, ANU Archives.

54 Green, A History of Australian Literature, Pure and Applied, 1355-6.

55 Jim Breen, Higher Education in Australia: Structure, Policy \& Debate (Melbourne: Monash University, 2002), sections 5.2, 5.3.

56 R.G. Collingwood, The Idea of History (Oxford: Clarendon Press, 1946). 
that reflective autobiographical material helped understand human and historical life: ' $[\mathrm{U}]$ nderstanding the meaning of history requires both an inner articulation of the temporal structures of our own experience and the interpretation of the external objectifications of others.' E.H. Carr was to use and popularise Dilthey's ideas in his lectures published in 1961 as What is History?. ${ }^{57}$ Concerns about the availability of sources that were sufficiently rich to sustain research on an Australian subject's consciousness were assuaged by the developing archives collections. Indeed, Fitzhardinge's job at the Commonwealth National Library from 1934 to 1946 had been Historical Research Officer in charge of Australian collections. ${ }^{58}$ Australia's national archives were separated from the National Library in $1954 .{ }^{59}$ As collections of papers developed, specialist Australian biographical bibliographies also appeared. ${ }^{60}$

More difficult to overcome, however, was a prejudice against biography. Francis West argued that historians such as Sir Lewis Namier, noted historian of the British Parliament, and the Cambridge historian and Tudor specialist Geoffrey Elton belittled biography. To some extent, West misread both historians' 'opposition' to biography; the point is that they both grappled with the relationship between the individual and human nature. ${ }^{61}$ West was right to argue, however, that academic historians had shunned biography; in the twentieth century, biography had been the work of 'non-historians'. ${ }^{62}$ The rise of structuralism and social history undermined explanations based on the role of the individual in history. Hancock devoted a chapter of his Professing History to these issues, explaining historians' reluctance to write biography and criticising that reluctance. He argued that during the postwar period, historians had been "unduly subservient to the then fashionable doctrine that history is always made by "impersonal forces, never persons". He lamented the popularity of Marxist ideas of history from below, and sociological ideas of statistical

57 H.P. Rickman, ed., Meaning in History: W. Dilthey's Thoughts on History and Society (London: Allen \& Unwin, 1961), 15; E.H. Carr, What is History? (New York: Knopf, 1962).

58 Peter Cochrane, Remarkable Occurrences: The National Library of Australia's First 100 Years (Canberra: National Library of Australia, 2001), 27.

59 See, for instance, Hilary Golder, Documenting a Nation: Australian Archives - The First Fifty Years (Canberra: Australian Government Publishing Service, 1994).

60 See Ulrich Ellis, Select Bibliography of Australian Political Biography and Autobiography (Canberra: Ulrich Ellis, 1958).

61 See, for instance, Linda Colley, Lewis Namier (London: Weidenfeld \& Nicolson, 1989), 72-89.

62 Francis West, Biography as History: The Annual Lecture delivered to The Australian Academy of the Humanities at its Fourth Annual General Meeting at Canberra on 15 May 1973 (Sydney: Sydney University Press for the Australian Academy of the Humanities, 1973), 1. 
averages that had undermined biography. ${ }^{63}$ More prosaically, Hancock was all too aware of how a dictionary of biography would in turn help to promote biography. As he argued to the ANU council in May 1962, when I started work on Smuts, I found good cause to curse the lack of a South African DNB ... If a Dictionary had existed, I should have been saved a year or more of finicky work', tracking down references to hundreds of individuals. ${ }^{64}$

As Hancock convinced others it would, the $A D B$ was established and proved to be the midwife of much Australian biographical practice. So, initially based on a plan Ellis proposed, with the cooperation of the state universities, and the general public, the $A D B$ began. Articles started to be drafted in 1959 and the first two volumes of the $A D B$ were published in 1966 and 1967. Retrospectively, delivering in 1973 the annual lecture to the Australian Academy of the Humanities, West credited the 'Past President, Sir Keith Hancock, and his official ancestor as Chairman of the Australian Humanities Research Council, Professor James Auchmuty' for regarding biography as 'the proper concern' of an historian over the objections of some distinguished historians, and for helping turn around attitudes. Instead of resorting to Britain, students were born and bred in Australia. Hancock welcomed the burgeoning of Australian biography under his supervision. For example, 10 per cent of the first $60 \mathrm{PhDs}$ at the ANU were biographies and a number of others were biographical. This was not surprising, given that potential supervisors Fitzhardinge, Hancock and Manning Clark had written and were writing biographies, were involved in the $A D B$ project, were writing memoirs and were being interviewed about their lives; in Clark's case in 1967 as part of pioneering series of interviews by the oral historian Hazel de Berg. ${ }^{65}$

63 Hancock, 'My Particular Person', in Professing History, 43-65.

64 Hancock Notes [towards a history of the ADB], Box 69, Q31, ADBA, ANUA. Hancock's 'prehistory' paper has not survived but his speaking notes for the ANU Council meeting of 11 May 1962 were comprehensive.

65 W.K. Hancock, Smuts (2 vols; Cambridge: Cambridge University Press, 1962-8); L.F. Fitzhardinge, William Morris Hughes: A Political Biography (2 vols; Sydney: Angus \& Robertson, 1964-78). Hazel de Berg interviewed Clark on 25 May 1967, NLA, about his childhood, his work and how he collected his material, and Bernard Smith in 1975. The National Library holds interviews of Clark by a succession of interviewers, including Hazel de Berg, 1967 (DeB 253-54), Don Baker, 1985 (TRC 1187), Neville Meaney, 1986-87 (TRC 2053), Michelle Rowland, 1986 (TRC 2141) and Terry Lane, 1990 (ROH 907.2092 C594). ANU had its own Oral History Program in the 1980s and 1990s, which included Manning Clark (1990 and 1991) and Robin (Bob) Gollan (1993). Other historians who wrote their autobiographies such as John Molony (2008) and John Mulvaney (2010) were included as interviewees in a more recent oral history project focusing on the ANU Emeritus Faculty. 
From the outset, the chairs of the working parties across the country were contributing authors: Gregory McMinn (Newcastle), Edwin Tapp (New England), Bede Nairn (NSW), Allan Morrison (Queensland), Harold Finnis (South Australia), Geoffrey Serle (Victoria), Frank Clifton Green (Tasmania) and Frank Crowley (Western Australia), along with many of the working party members. McMinn, Nairn, Morrison and Serle were among the 1 per cent of $A D B$ authors who contributed 20 or more articles. Even the publisher, Gwyn James, contributed four $A D B$ articles. Many working party and national committee members having written $A D B$ articles went on to write full biographies. To give just one example of this much-observed phenomenon, Auchmuty was the first member listed on the $A D B$ 's National Committee. ${ }^{66}$ In 1966, Auchmuty's $A D B$ entry on Governor John Hunter was published, in 1968 he published a full biography on Hunter, and in 1971 he edited a collection of 'ADB colleagues' on Australia's first governors, consisting of himself on Hunter, Margaret Steven on Arthur Phillip, Michael Roe on Philip Gidley King, John Bach on William Bligh, Marjorie Barnard on Lachlan Macquarie and Ruth Teale on Thomas Brisbane. ${ }^{67}$ Barnard went on to write $2 A D B$ articles, Auchmuty 3, Bach 4, Steven 24, Roe 33, and Teale $57 .{ }^{68}$

\section{Kick-starting Australian ego-histoire: From national to familial tribes}

Crawford's survey of 'Australian' biographical works between 1933 and 1947 lists just 35 monographs in 15 years. There followed a tsunami of life writing in Australia. A search of the National Library of Australia catalogue, Trove, in 2013 lists over 13,000 'Australian biographical' works. ${ }^{69}$ If one breaks it down by decade, the rising popularity of biography is clear and other patterns can be discerned. Of course, counting is problematic. Crawford's counting was biased, as was Popkin's in arguing for 1983 as a crucial turning point in Australian historians' autobiographical writing, following Nora’s work. Popkin's calculations only stand up if we venture

66 See, Nolan and Fernon, The ADB's Story, 32.

67 J.J. Auchmuty, 'Hunter, John (1737-1821)', Australian Dictionary of Biography, Volume 1, (MUP), 1966; John Hunter (Melbourne: Oxford University Press 1968); The First Australian governors (Melbourne: Oxford University Press, 1971). See also Kenneth R. Dutton, Auchmuty: The life of James Johnston Auchmuty (1909-1981) (Brisbane: Boombana Publications, 2000).

$68 A D B$ Author Database.

69 Trove, National Library of Australia online catalogue, catalogue.nla.gov.au/Search (accessed 15 December 2013). 
judgements by which earlier works can be dismissed as being of poor 'quality'. For example, Francis Patrick Clune (1893-1971) wrote over 60 books, including accounts of Frank Gardiner (1945) and Ben Hall (1947) and, in 1933, an autobiographical work in Try Anything Once. A number of historians also wrote autobiographical work long before egohistoire popularised the genre: Garnet Vere Portus (1883-1954) wrote his autobiography, Happy Highways, in 1953; Alan Moorehead (1910-83) wrote his, A Late Education: Episodes in Life, in 1970; and Paul Hasluck (1905-91), Mucking Around, in 1977 and so on. ${ }^{70}$ Patsy Adam-Smith even published a volume of her autobiography in 1964 before writing history. ${ }^{71}$ These all predate Popkin's 'count', but his analysis is based on there being little historians' biography and autobiography before 1983 . He was, of course, concentrating on academic historians.

Despite the undercounting, was there a turning point in the 1980s nonetheless? The evidence suggests that there was, but that defining it is not simply a matter of volume. Hermione Lee has observed we can identify the 'popularity of certain kinds of biographies in different countries, periods and cultures ... [which] provides an insight into that society. What does that society value, what does it care about, who are its visible - and invisible - men and women?'72 In Australia, for instance, radical historians concentrated upon the close relationship between the 'being' of the human finding its essence in the being of place. A wave of work appeared, especially in the 1970s and 1980s on Ned Kelly, Peter Lalor, Henry Lawson and William Lane - bushrangers, militants, poets and socialists. ${ }^{73}$ Especially in the wake of transnationalism, subjects have since diversified: there is considerable interest in the recent past but, above all, historians have written family biographies and memoirs as much as topos.

70 Francis Patrick Clune, Try Anything Once: The Autobiography of a Wanderer (Sydney: Angus \& Robertson, 1933); Portus, Happy Highways; Alan Moorehead, A Late Education: Episodes in a Life (London: Hamish Hamilton, 1970); Paul Hasluck, Mucking About: An Autobiography (Melbourne: Melbourne University Press, 1977). Portus was an academic historian, at the University of Adelaide, while the others did not work within the academy.

71 Patsy Adam-Smith, Hear the Train Blow: An Australian Childhood (Sydney: Ure Smith, 1964).

72 Hermione Lee, Biography: A Very Short Introduction (Oxford: Oxford University Press, 2009), doi.org/10.1093/actrade/9780199533541.001.0001.

73 See Lloyd Ross, William Lane and the Australian Labour Movement (Sydney: Forward Press, 1937); John Molony, I am Ned Kelly (Ringwood, Melbourne: Allen Lane, 1980); Robin Gollan, Revolutionaries and Reformists: Communism and the Australian Labour Movement, 1920-1955 (Sydney: Allen \& Unwin, 1985); and Bede Nairn, The 'Big Fella': Jack Lang and the Australian Labor Party 1891-1949 (Melbourne: Melbourne University Press, 1986). 
So Australian biography has been characterised by three principal developments of late. First, sometime in the era spanning the end of the twentieth and the beginning of the twenty-first century, the connection with time and place was loosened, with new transnational themes emerging. This was in keeping with wider developments. Whereas Frank Moorhouse's Grand Days, the first in a trilogy - about a young Australian, Edith Campbell Berry, at the League of Nations - was excluded from consideration for the Miles Franklin Prize in 1994 because it was deemed not to have sufficient Australian content, this was controversial and his second volume in 2001, Dark Palace, won. Similarly, if we survey the National Biography Award (NBA) we can see the question about 'quintessential' Australian biography broadening. Geoffrey Cain agitated for the foundation of the NBA, a biannual award in 1996 and annual since 2000, which the State Library of New South Wales administers. Cain with fellow philanthropist Michael Crouch have provided the funding. 'Australian biography' had been broadly defined:

The subject of the work is to be an Australian or have made a significant contribution to Australia. Other subjects may be considered if the author is an Australian citizen or permanent resident and the work provides a particularly Australian perspective of the subject. ${ }^{74}$

About half the winners have been unambiguously Australians writing about Australian subjects. Brian Matthews's biography of historian Manning Clark won in 2010. ${ }^{75}$ Sheila Fitzpatrick's account of being a Soviet historian working in Soviet archives and teaching and writing in the United States was shortlisted in $2014 .{ }^{76}$ Of course, this international dimension is particularly pertinent in a country Europeans settled from 1788; which attracted 2 million migrants between 1945 and 1965; and with a quarter of Australians being 'foreign born' in 2007, and more than 43 per cent of whom were either born overseas themselves or had one

74 'National Biography Awards', State Library of New South Wales website, www.sl.nsw.gov.au/ about/awards/national_biography (accessed 16 December 2013). See also Melanie Nolan, 'Country and Lives: Australian Biography and its History', in Cercles: Revue Pluridisciplinare du Monde Anglophone, no. 35 (March 2015), 96-117.

75 Brian Matthews, Manning Clark: A Life (Sydney: Allen \& Unwin, 2008).

76 Sheila Fitzpatrick, My Father's Daughter: Memories of an Australian Childhood (Melbourne: Melbourne University Press, 2010); Fitzpatrick, A Spy in the Archives (Melbourne: Melbourne University Press, 2013). 
parent who was born overseas. ${ }^{77}$ So there is increasing acknowledgement of the variety of Australian lives. There is now a growing literature on the relationship between self and nation. ${ }^{78}$ As Ros Pesman notes:

To place Australian experience in a wider framework is not to reject Australian nationality and culture, but to emphasize their connections with the rest of the world, their porous and permeable qualities. Identity and nationality are, like everything else, not fixed structures, but processes in the making. There is no Australian 'identity', only 'identities', and these have been forged abroad as well as at home, in contact and in collision with others, as well as in isolation. ${ }^{79}$

By 2014, the former director of the Art Gallery of New South Wales, Edmund Capon, was declaring that Australia's greatest visual artists, including twentieth-century artists Sidney Nolan, Arthur Boyd and Russell Drysdale, were virtually unknown overseas or else ignored because their work was 'too strongly defined by place' ${ }^{80}$ By contrast, Capon argued, Australian literature had more international impact because cosmopolitan themes were increasingly harnessed to national stories. Transnational biography has become fashionable and had impact starting, as Popkin noted, with Conway's The Road from Coorain. ${ }^{81}$ The 'system of cultural signification' that makes up the nation is ambivalent precisely because it is in constant flux.

Second, with diversity have come more searching questions about biography itself, notably concerning its gendered character. There have been an increasing number of women historians' memoirs and biographies. ${ }^{82}$ Yet just two women, Jessie Webb and Kathleen Fitzpatrick, are among the 10 historians Macintyre and Thomas profiled in their 1995 collection, The Discovery of Australian History. ${ }^{83}$ Women made up 11 per cent, or 13 of the 118, historians profiled in the 1998 Oxford Companion to Australian History. Moreover, women historians such as Alexandra Hasluck, Kathleen Fitzpatrick, Catherine Berndt, Maie

77 'Population', Australian Bureau of Statistics, Migration, Australia, 2008-09 (cat. no. 3412.0).

78 See Suzanne Falkiner, The Writers' Landscape: Wilderness (Sydney: Simon \& Schuster, 1992).

79 Ros Pesman, Duty Free: Australian Women Abroad (Melbourne: Oxford University Press, 1996), 17.

80 Sydney Morning Herald, 10 September 2014.

81 Ker Conway, The Road from Coorain.

82 See Jane Carey and Patricia Grimshaw, Women Historians and Women's History: Kathleen Fitzpatrick (1905-1990), Margaret Kiddle (1914-1958), and the Melbourne History School (Melbourne: Department of History, University of Melbourne, 2001).

83 Stuart Macintyre and Julian Thomas, eds, The Discovery of Australian History 1890-1939 (Melbourne: Melbourne University Press, 1995). 
Casey and Nettie Palmer did not get as much space as the men they were married to, and Ann Blainey, author of five biographies, got none at all - although, to be fair, her award-winning biography on Dame Nellie Melba was written after the companion had been published. The Encyclopedia of Women and Leadership in Twentieth-Century Australia lists 73 women historians out of 680 individual entries, about 11 per cent, albeit including living historians. ${ }^{84}$ The $A D B$ will eventually have perhaps four times as many historians: certainly those who died before 1991 mentioned in the Companion are all in the $A D B$. The Oxford Companion is revealing because it discusses the schools, groups and ideas as it profiles the 118 historians, in much more detail than the $A D B$. Moreover, a small number have substantial entries and are consequently signalled as more important: C.E.W. Bean (1879-1968), Geoffrey Blainey (1930- ), Geoffrey Bolton (1931-2015), Noel Butlin (1921-91), Vere Gordon Childe (1892-1957), Manning Clark (1915-91), Timothy Coghlan (1855-1926), Brian Fitzpatrick (1905-65), Robin Gollan (1917-2007), Keith Hancock (1898-1988), Paul Hasluck (1905-93), John Mulvaney (1925-2016), Stephen Roberts (1901-71), Ernest Scott (1867-1939), and Russel Ward (1914-95). Max Crawford is relegated to a short entry; much of the analysis of him and his 'school of history' was published after 1995. ${ }^{85}$ Women, however, lack prominence then and now. Biographies on women do raise unsettling questions about 'the search for identity in Australian biography'. Bill Wilde notes that Matthews, in his biography of Louisa Lawson, female newspaper proprietor and mother of poet Henry Lawson, asks the same questions that Virginia Woolf, author and an experimenter in biographical methodology, asked: the central problem of biography was how to weld together the 'granite-like solidity' of truth or fact and the 'rainbow-like intangibility of personality or character'. ${ }^{86}$ Despite all the 'multivocality', Ann Curthoys noted in her Russel Ward

84 Australian Women's Archives Project, The Encyclopedia of Women and Leadership in TwentiethCentury Australia, www.womenaustralia.info/leaders/about.html (accessed 26 June 2015).

85 Robert Dare, 'Max Crawford and the Study of History', in Macintyre and Thomas, The Discovery of Australian History, 174-91; Stuart Macintyre and Peter McPhee, eds, Max Crawford's School of History (Melbourne: Department of History, University of Melbourne, 2000); Fay Anderson, An Historian's Life: Max Crawford and the Politics of Academic Freedom (Melbourne: Melbourne University Press, 2005); Robert Dare, 'Theory and Method', in Fay Anderson and Stuart Macintyre, eds, The Life of the Past: The Discipline of History at the University of Melbourne, 1855-2005 (Melbourne: Department of History, University of Melbourne, 2006), 339-53.

86 W.H. (Bill) Wilde, The Search for Identity in Australian Biography (The 1990 Colin Roderick Lectures; Townsville, Qld: Foundation for Australian Literary Studies and James Cook University, 1991); Brian Matthews, Louisa (Melbourne: McPhee Gribble, 1987); Virginia Woolf, Granite and Rainbow (London: Harcourt Brace, 1958), 149. 
Annual Lecture in 1992: 'While we might undertake a feminist analysis of the gendered character of the debate about conceptions of the nation, we have not yet been able to redefine what national identity might mean. ${ }^{87}$ In terms of biography, while national identity might not have been redefined, conceptions of appropriate subjects and sources have led to consideration of networks, particularly familial ones, and increasingly this tendency has gender implications. ${ }^{88}$

Indeed, thirdly, the most notable recent pattern is not 'simply' the inclusion of women historians but that, increasingly, male and female historians are both writing about their families as much as themselves. Of course this is part of a wider phenomenon, too. As Hans Render and others have shown, this interest in families is part of the tendency towards interiority (biography) and has been attended by an interest in the social meaning of an individual life. ${ }^{89}$ Linda Colley has shown the global significance of the life of Elizabeth Marsh. ${ }^{90}$ Family-centred history is another method increasingly used by historians themselves, such as Alison Light in her family account, Common People. ${ }^{11}$ Frank Vandiver noted the advantages of family biography more generally:

Theoretically the advantage of a family biography is that it allows a perspective that delves into the 'thick issues of relationships' and which is not slanted by a focus on any one participant (or his or her version of the historical allowing character and personality to more fully emerge. As a result the biographer has more 'clay' from which to interpret meanings, nuances, and appreciations. ${ }^{92}$

Searching 'Australian family biographies' in Trove by decade reveals starkly the trajectory of the popularity of this new genre. ${ }^{93}$ As others have noted, the focus of Australian historians' biographies seems to be moving from

87 Ann Curthoys, Australian Legends: Histories, Identities, Geneaologies (Armidale, NSW: University of New England Union, 1992).

88 See Alison Light, Common People: The History of an English Family (London: Fig Tree, 2014), xxvii ff., for a discussion on changing attitudes among professional historians to family history.

89 Hans Renders and Binne de Haan, eds, Theoretical Discussions of Biography: Approaches from History, Microhistory, and Life Writing (Lewiston, NY: The Edwin Mellen Press, 2013).

90 Linda Colley, The Ordeal of Elizabeth Marsh: A Woman in World History (New York: Pantheon Books, 2007).

91 Light, Common People, 34.

92 Frank E. Vandiver, 'Biography as an Agent of Humanism', in Stephen B. Oates, ed., Biography as High Adventure: Life Writers Speak on their Art (Amherst: University of Massachusetts Press, 1986). 93 The rate has dramatically increased from 1950-1959 (2,119), 1960-1969 (2,040), 19701979 (2,432), 1980-1989 (3,789), 1990-1999 (6,803) to 2000-2009 (135,046), trove.nla.gov.au/ result?q=\%27Australian+family+biographies\%27 (accessed 15 September 2017). 
nation to family. ${ }^{94}$ Historians, including David Walker, John Rickard and Graeme Davison, are consulting their own personal biochemical archives to produce family histories. ${ }^{95}$ When macular degeneration dimmed his eyesight, for instance, Walker turned to family history, something he had previously avoided. He had 'to rethink the kind of history I was able to write. I had to find another, more personal voice and another way of writing. The mix of the historical and the personal seemed promising'. How, he asks, can we reconcile or accommodate the competing claims of the big events of history with the constant flow of small, day-to-day trials and pleasures? He was disconcerted to find that 'the lives, values and preoccupations of most of my forebears had no place in the national story', so he has rewritten the national story. The trend is similar among biographies of historians. ${ }^{96}$ And the list of historians writing their 'family memoirs' continues to grow apace: in the last decade, in addition to Walker, Rickard and Davison, there have been Tim Bonyhady, Marjorie Theobald, Sheila Fitzpatrick, Jill Roe, and others such as John Molony and Ann Moyal, writing second instalments. ${ }^{97}$ These accounts include female, Chinese, working-class and Irish relatives. Some are intergenerational, and some are about circles and networks. Russel Ward wrote his autobiography, A Radical Life; a generation later, his daughter Biff wrote hers. ${ }^{98} \mathrm{~A}$ range of related biographies, such as that by Keith McKenry on John Meredith, have also appeared. ${ }^{99}$ Similarly, Don Watson wrote a

94 John Rickard, 'Pointers to the Future of Family History', review of Good Living Street: The Fortunes of my Viennese Family by Tim Bonyhady, Australian Historical Studies, 44:3 (2011), 457-62, doi.org/10.1080/1031461X.2013.817289.

95 David Walker, Not Dark Yet: A Personal History (Sydney: Giramondo, 2011); John Rickard, An Imperial Affair: Portrait of an Australian Marriage (Melbourne: Monash University Publishing, 2013); Graeme Davison, Lost Relations: Fortunes of my Family in Australia's Golden Age (Sydney: Allen \& Unwin, 2015).

96 See, for instance, Elizabeth Kleinhenz, A Brimming Cup. The Life of Kathleen Fitzpatrick (Melbourne: Melbourne University Press, 2013); Geoffrey Bolton, Paul Hasluck: A Life (Perth: UWA Publishing, 2014).

97 Tim Bonyhady, Good Living Street: The Fortunes of my Viennese Family (Sydney: Allen \& Unwin, 2011); Marjorie Theobald, 'The Wealth Beneath their Feet: A Family on the Castlemaine Goldfields (Melbourne: Arcadia, 2010); Jill Roe, Our Fathers Cleared the Bush: Remembering Eyre Peninsula (Adelaide: Wakefield Press, 2016); John Molony, Luther's Pine: An Autobiography (Canberra: Pandanus Books, 2004); Molony, By Wendouree: Memories 1951-1963 (Ballan, Vic.: Connor Court Publishing, 2010); Ann Moyal, $A$ Woman of Influence: Science, Men \& History (Perth: UWA Publishing, 2014).

98 Russel Ward, A Radical Life: The Autobiography of Russel Ward (South Melbourne: Macmillan, 1988). See, for example, Don Watson, Brian Fitzpatrick: A Radical Life (Sydney: Hale \& Iremonger, 1979); and Amirah Inglis, The Hammer \& Sickle and the Washing Up: Memories of an Australian Woman Communist (South Melbourne: Hyland House, 1995). Biff Ward, In my Mother's Hands: A Disturbing Memoir of Family Life (Crow's Nest, NSW: Allen and Unwin, 2014).

99 Keith McKenry, More than a Life. John Meredith and the Fight for Australian Tradition (Sydney: Rosenberg, 2014). 
biography of Brian Fitzpatrick, and there are biographies of and by his first wife and his daughter. ${ }^{100}$ Most recently Judith Armstrong has written a biography of Dymphna Lodewyckz, 'wife, mother, research assistant and unofficial editor for her husband', Manning Clark. ${ }^{101}$

\section{Conclusion: Fuller circumstances in which historians construct history}

In this essay, I have considered the history of biographical practices of Hancock, the $A D B$ and the wider historical community more generally. During the middle years of the twentieth century, many historians did not regard biography as the best practice of history. Hancock argued in 1976 that Collingwood and others were wrong when they said that biography was 'poor history'. He thought that they were overreacting to the excesses of pseudo- and psycho-biographies by Lytton Strachey and others and, more recently, social history perspectives:

I found rather more perplexing that assertion made by another philosopher R.G. Collingwood that every work of biography is not only non-historical but anti-historical. It seems to me that Collingwood was hitting below the belt, for he also had published an autobiography ... I had applauded his contention that the subject-matter of history is past experience re-enacted in the historian's mind; but I parted company from him when he went on to argue that human experience is all mind and no body. ${ }^{102}$

Hancock increasingly became interested in biographical consciousness and, first, topos or locality in Australians' biographies and, second, in family. As noted at the outset, conspicuously early, Hancock himself wrote about his origins from the manse but very little about 'my wife'; there were many more references to his first wife, Theaden, in Professing History in 1976. By the time of his death, he gave approval to Davidson to write the biography. The $A D B$ has also started to create 'big data' for families and to mediate systematically between families and broader developments, navigating family relations structurally and historically by

100 Watson, Brian Fitzpatrick; Kathleen Fitzpatrick, Solid Bluestone Foundations; Kleinhenz, A Brimming Cup; Sheila Fitzpatrick, My Father's Daughter: Memories of an Australian Childhood (Melbourne: Melbourne University Press, 2010); and A Spy in the Archives (Melbourne: Melbourne University Press, 2013).

101 Judith Armstrong, Dymphna (North Melbourne: Australian Scholarly Publishing, 2016).

102 Hancock, Professing History, 53-5. 
mapping families. Rather than just linking to other family members in its websites, it is naming the relationships between family members (mother, grandfather and so on) in order for complex family trees across multiple generations to be automatically generated as a visualisation and be easily navigated, including of course for historians in the $A D B$. This perspective undermines elitist and unrepresentative approaches.

Hancock might have had a three-cornered life, have been 'neither a founder of history in a new Australian university, and have not spent a career building the subject in a particular institution', but he was instrumental in the foundation of the $A D B$ and in promoting life writing in Australia. ${ }^{103}$ Over the years, the $A D B$ has been itself subject to the same forces of change as those affecting Hancock. It is now commissioning and editing lives that are perilously close to the present, such as those who died between 1991 and 2000. Hancock not only wrote mainly about events in his own lifetime but he also wrote about events in which he was himself involved, for example chairing the Namirembe Conference - which created a new constitutional monarchy for Buganda in 1954 while writing on the Commonwealth. Hancock began writing his second volume of memoirs with two chapters he had 'left over' from his history of his involvement in protest against the Black Mountain tower in Canberra. He came to see autobiography, and biography, both as part of the task of professing history. It should be noted that in his wake, while there are 306 biographies of historians in the $A D B$ for the period between 1788 and 1990, the proportion of historians in the $A D B$ overall is more than the proportion of Indigenous Australian subjects, although the $A D B$ has a current project to rectify this. ${ }^{104}$

While it is commonplace today to regard biography as just one form of history, many argue that autobiography and memoir can involve history but are, nevertheless, conceptually distinct. Others question these distinctions. ${ }^{105}$ Hancock came to see varieties of life writing on a continuum, and this is the position argued in this essay too. He was involved in the events of the time and knew some of the subjects he wrote

103 Julian Thomas, 'Keith Hancock: Professing the Profession', in Macintyre and Thomas, The Discovery of Australian History, 146.

104 Melanie Nolan, “'Insufficiently Engineered”: A Dictionary Designed to Stand the Test of Time?' in Nolan and Fernon, The ADB's Story, 26; Biography Footnotes, 15 (2015), 5.

105 Aurell, 'Autobiography as Unconventional History'; Robert A. Rosenstone, 'Invitation to Historians: Confessions of a Postmodern (?) Historian', Rethinking History, 8:1 (2004), 149-66, doi.org/10.1080/13642520410001649787. 
about. He researched his memoirs. Similarly, Australians' public lives are increasingly being placed in their familial and wider contexts. Whatever our view on these debates and approaches, the academic status of both memoir and biography has changed in the last three decades as subjectivity - once swept off the academic stage, particularly with postmodernism decreeing the 'death of the subject' - has now reappeared. ${ }^{106}$ While interest in the individual coherent self continues strongly outside the academy, within it historians have returned to this genre in recent years to write about themselves and/or other historians. Some interest in historians' personal and familial circumstances is prurient, some in keeping with a wider genealogical and family consciousness in the history. Much of it is motivated by the thought that how, and in what circumstances in all its fullness, one writes helps to understand the history that a historian constructs. 
This text is taken from Clio's Lives: Biographies and Autobiographies of Historians, edited by Doug Munro and John G. Reid, published 2017 by ANU Press, The Australian National University, Canberra, Australia.

dx.doi.org/10.22459/CL.10.2017.11 